\title{
Abraham Kuyper, ras en volk - en Suid-Afrika
}

\author{
P.J. Strauss \\ Dept. Ekklesiologie \\ Universiteit van die Oranje-Vrystaat \\ BLOEMFONTEIN
}

\begin{abstract}
Abraham Kuyper, race and nation and South Africa

In the past various Afrikaans-speaking theologians have applied viewpoints of the well-known Dulch scholar and reformed theologian Abraham Kuyper (1837-1920), in their support of apartheid. During the past decades this fact, as well as the question as to whether they interpreted Kuyper correct1y, has ofien been a point of discussion in various circles. What has, however, rarely functioned in the debate, is Kuyper's own reflection and stance on the apartheid of his time, and the way in which this reflection ties in with his reasoning in general and especially his concept of special and common grace.
\end{abstract}

The conclusion reached in this article is that Kuyper regarded the apartheid' of his time (over and against equalization) as a temporary measure. This point of view is also in line with the general principles implicit in his reasoning and reflection. It thus cannot be maintained that Kuyper would have supported apartheid permanently and within a static system.

\section{Tema in 'n probleemveld}

Die laaste woord in die wetenskaplike besinning oor die moontlike verbandtussen die standpunte van die veelsydige Nederlandse geleerde, Abraham Kuyper (1837-1920), en apartheid in Suid-Afrika, is nog lank nie gespreek nie. So dikwels as wat die vraag oor die steun uit reformatoriese kringe aan apartheid of afsonderlike ontwikkeling in hierdie debat opduik, so dikwels bestaan die moontlikheid dat die naam van Kuyper in die gesprek kan voorkom. (Vir 'n resente beskouing oor Kuyper en hierdie saak, vergelyk Smit, 1992:88.)

Oor die presiese verband tussen Kuyper en ' $n$ fundering van apartheid in SuidAfrika loop die menings in twee hoofrigtings uiteen.

Enersyds is (was?) sommige voorstanders van die apartheidsbeleid van oortuiging dat 'n behoorlike bestudering van Kuyper se standpunte oor rasse en volke - 
binne die raamwerk van sy kosmologie - jou tot geen ander opsie kan lei nie as steun aan, soos dit genoem word, 'veelvormige' of afsonderlike ontwikkeling in Suid-Afrika (vgl. Potgieter, 1956:7,11; 1978:17; NGK, 1966:90,93-95,112,114; Van Wyk, 1978:15). In hierdie aanspraak word hulle deur sommige felle kritici van die beleid toegegee. So meen Verkuyl dat teoloë wat 'n Bybelse 'bolwerk' aan ' $n$ beleid van politieke en ekonomiese 'eksploitasie' verskaf het, tereg in Kuyper se leer oor die skeppingsordeninge 'n aanknopingspunt kon vind (1968:31). Viljoen (1980:45) skryf 'n Christelik-nasionale ideologie en kollektiewe roepingsbewussyn toe aan Kuyper se konsep van die algemene genade. Hierdie ideologie en kollektiewe roepingsbewussyn, meen hy, kon by 'die' Afrikaner in sy steun aan apartheid waargeneem word.

Andersyds beweer ander kritici van apartheid dat die denksisteem van Kuyper misbruik of verkeerd verstaan is in die aanwending daarvan vir 'n fundering van die beleid (De Gruchy, 1984:107; Smit, 1989:54). In 'n konsentrasie op die bekende Stone-lesings van Kuyper uit 1898 kom De Gruchy (1984:108) tot die gevolgtrekking dat Kuyper van oordeel was dat die Calvinisme in wese demokraties is - die teendeel van die regeerstyl wat die voorstanders van apartheid bedryf het. En, hoewel versigtig bewoord, neig Smit (1989:54) tot dieselfde interpretasie: volgens hom het Kuyper nie apartheid gepropageer nie, maar die opheffing van ander bevolkingsgroepe.

Wat die probleem van die debat vererger, is die neiging by 'n groot aantal deelnemers om die volgende noodsaaklike aspekte af te skeep of totaal te negeer:

* 'n Evaluering van Kuyperuitsprake binne hulle historiese konteks (byvoorbeeld die Stone-lesings, soos gerig op 'n Amerikaanse gehoor en vanuit Kuyper se Europese agtergrond), sowel as die breë verband van sy hele teologies-wysgerige denksisteem. Gevolgtrekkings word dikwels gemaak op grond van enkele, geselekteerde sitate (vgl. die opmerking van Kinghorn, 1986:62; en as voorbeeld De Gruchy, [1984]) of publikasies van Kuyper, of na aanleiding van persepsies wat oor hom in omloop is (De Gruchy [1979] en Viljoen [1980] raadpleeg nie een werk van Kuyper self nie!).

* Die voorkoms van skynbare teenstrydighede by Kuyper, wat veroorsaak word deur sy retoriese skryfwyse en die fragmentariese aard van sy dikwels lang artikelreekse (twee van sy groot werke, De Gemeene Gratie (1902) en Pro Rege (1911-1912), albei bestaande uit drie dele, spruit byvoorbeeld uit reekse in die gereformeerde tydskrif De Heraut - Velema, 1989:59). Skynteenstrydighede, so stel Van Ruler dit, want "In wezen blijft Kuyper zigzelf steeds gelijk" (s.j.:92). Hierdie oênskynlike teenstrydighede word duidelik weerspieël in die versigtige en kroniekagtige artikel van Smit (1989). 
* Die oortuiging wat by Kuyper self aanwesig was dat hy in die verlengde van die denktradisie van Calvyn werk - om die beginsels daarvan te verdiep, te verbreed en van vreemde bestanddele te suiwer. Hyself het dan ook nie geskroom om na homself as Neo-Calvinis te verwys nie (Ridderbos, 1947:315). In dié proses wou hy deurgaans alle sake vanuit 'n bepaalde, bykans konstante, prinsipiële raanwerk beoordeel. Die veelgeroemde grondstelling van Kuyper (1930:32) het hier betrekking:

... geen enkel stuk van onze denkwereld is hermetisch te scheiden van de andere delen; en geen duimbreed is er op heel 't erf van ons menschelijk leven, waarvan de Christus, die aller Soverein is, niet roept: 'Mijn!'

* Kuyper se eie toepassing van sy uitgangspunte op die rasse- en volkeresituasie in wat vandag bekend staan as Suid-Afrika - 'n naam wat Kuyper self gebruik en aan die mode van sy tyd ontleen het. (Wat hy bedoel met die twee begrippe, rasse- en volkeresituasie, kom later aan die orde.)

Hoewel hy in ander stukke sydelings na Afrika en die 'Boere' verwys, kom hierdie toepassing hoofsaaklik in twee publikasies voor: sy Plancrus-rede van 1884 en De crisis in Zuid-Afrika van 1900. Sy Plancius-rede is op 11 Maart 1884 in Amsterdam as toespraak voor die vakbond Patrimonium gelewer en was gerig tot die Transvaalse Deputasie na die Londense Konvensie. Laasgenoemde publikasie, De crisis in Zuid-Afrika, verskyn eers in die Franse tydskrif Revue des deux Mondes en word later in Nederlands, Engels, Duits en Sweeds vertaal. Die jeugdige Nederlandse koningin Wilhelmina betuig in April 1900 ook haar instemming met die stuk (Strauss, 1983:80).

Om die probleemveld met betrekking tot Kuyper, ras en volk en Suid-Afrika op te som: Kuyper word verskillend geinterpreteer, dikwels buite konteks aangehaal of gebruik en sy eie siening van die saak - soos vergestalt in sy tyd - kry nouliks aandag.

Daarom konsentreer hierdie stuk in hoofsaak op Kuyper se eie houding teenoor die oortuigings en optrede van Afrikaners teenoor anderskleuriges in die laaste jare van die vorige eeu, en op 'n verklaring daarvan vanuit sy eie denkraamwerke en agtergrond. Waar dit toepaslik is, word enkele voorbeelde van hoe gereformeerdes hier te lande sy denke ter fundering van apartheid aangewend het kortliks bespreek. 'n Aantal slotgevolgtrekkings voltool die prentjie.

\section{Kuyper en die 'apartheid' van sy tyd}

In sy Plancius-rede noem Kuyper die Transvaalse Boere stam- en geesgenote van die Nederlandse anti-rewolusionêres of gereformeerdes met 'n "hooge taak en 
heilige roeping in ... Afrika" (Kuyper, 1884:22). Hy beskou die Boere as pioniers van die Christelike beskawing in Suidelike en Sentraal-Afrika. Volgens hom moet hulle die instrument wees deur wie God se seën ook die volke bereik wat onder die vloek van Gam "gebogen liggen" (1884:22). In dié proses moet die Transvalers nie valse humaniteitsbegrippe oor die swart mense navolg deur te veel vryheid - in die Europese sin van die woord - aan hulle te verkondig nie, want dit sal tot selfmoord lei. Volgens Kuyper (1884:21) is die Boere besig met egte Christelike politiek deur die swarte te aanvaar soos hy is en hom vandaar "allengs" uit sy laagte op te hef, "om hem eens met u gelijk te maken". Kuyper formuleer die kern van die verhoudingsprobleem dus as ' $n$ verskil in 'n samelewingsomvattende Christelike beskawing. Hy propageer eweneens omvattende opheffing en ontwikkeling, maar algemene 'demokrasie' of die verkryging van politieke vryhede deur anderskleuriges verplaas hy oënskynlik na die verre toekoms. Hy maak ook nie gewag van tipiese rasse- of volkereverskille (veelvormigheid) as legitieme verdelingsbeginsel vir aparte ontwikkeling nie.

Sestien jaar later, in sy De crisis in Zuid-Afrika (1900), waarin hy tydens die Anglo-Boereoorlog as Europese pleitbesorger optree vir die saak van die Republieke van die Oranje-Vrystaat en Transvaal, sit Kuyper hierdie benadering voort.

In die uitbouing van sy opvatting dat die Boere die draers is van die Christelike (respektiewelik Calvinistiese) beskawing, haal hy die historikus Theal aan om die 'onbeskaafdhede' van anderskleuriges te illustreer. Brittanje se beleid van gelykstelling, soos gepropageer deur veral die sendelinge van die Londense Sendinggenootskap, word sodoende verkeerd bewys. Hierdie gelykstellingsbeleid kom volgens Kuyper bowendien op uit 'n liberalistiese en humanistiese verheerliking van die natuurmens (Kuyper, 1900:16), dit getuig van metodistiese heftigheid en maak die Calvinistiese en beskaafde Boer tot huigelaar (ibid., 1900:19) en vyand van die mensdom (ibid., 1900:16).

Die high-life beskawing in die hoogste kringe in Londen staan gewis op 'n hoër vlak as iets soortgelyks onder die Boere, maar "uit een zedelijk oogpunt" hoef laasgenoemde vir geen Europese "natie" terug te staan nie (ibid., 1900:42-43). As Calvinistiese Christene is die Boere, in teenstelling met die Engelse sendelinge, nie sentimenteel van aard nie, maar prakties; daarom het hulle begryp dat die anderskleuriges tot "een lager ras" behoort en dat dit dwaasheid sou wees om hulle in die gesins-, maatskaplike en politieke lewe as gelykes te behandel. Hierdie insig het ook by die Boere gelei tot die sterk afkeur van bloedvermenging: hulle sou dit dan as "een soort van bloedschande" beskou (ibid., 1900:16).

Volgens Kuyper - en hy haal Switserse sendelinge in dié verband aan - is die Boere nie teen die sending onder die anderskleuriges as sodanig gekant nie, maar staan hulle negatief teenoor mense soos Read, Philip en Van der Kemp. Hierdie 
politieke padvindersendelinge het immers die Engelse publiek en regering teen die Boere opgehits (ibid., 1900:20). Niemand kan egter beter met die anderskleuriges omgaan as Boerepatriarge nie: hulle het 'n verhouding met die anderskleuriges soos dié van ouers teenoor kinders. Deur hulle beskawende invloed het die Boere die anderskleuriges aan arbeid gewoond gemaak en hulle sedelike en beskawingspeil verhoog. Selfs toe die mans in 1900 gedurende die oorlog die vroue alleen op die plase moes laat, was daar nie opstande nie, maar rus en kalmte (ibid., 1900:19).

Dit is opvallend dat Kuyper die beskawings- of ontwikkelingsargument (opheffing volgens Smit?) binne sy verstaan van watter lewensbeskoulike kragte in Suid-Afrika werksaam is, as enigste grond vir sy regverdiging van die 'apartheid' van die Boer van sy tyd aanwend.

Hierdie benadering van Kuyper, gesien teen die agtergrond van ons probleemstelling, laat onmiddellik ' $n$ aantal hoogs interessante vrae na vore kom. Die eerste daarvan is: hoe kom Kuyper by hierdie standpunt uit? Pas dit binne sy breë teologies-wysgerige denkraamwerk? Is hierdie benadering situasiegebonde of algemeen geldend - vir alle tye en situasies? Verder, was Kuyper 'n rassis in 'n gekwalifiseerde sin met 'n rasgeoriënteerde standpunt oor beskawingsontwikkeling, en waaraan is die spore van kulturele meerderwaardigheid wat by hom uitslaan, toe te skryf?

Smit (1989) is van oordeel dat dit nie die ware Kuyper is wat hier aan die woord is nie. Die elemente van kulturele chauvinisme is nie eie aan die tetiese denker van De Gemeene Gratie, Pro Rege en Het Calvinisme nie, maar moet toegeskryf word aan Kuyper se begeerte om die noodlydende Boere te bemoedig (1989:51). Volgens Smit verteenwoordig Kuyper se benadering tot die 'apartheid' van die laat negentiende eeu dus ' $n$ klein en emosioneel gemotiveerde afstappie vanaf die lyn van die eintlike Kuyper. Lubbe en Britz (1992:9,10), hoewel meer geinteresseerd in Kuyper se houding oor die Anglo-Boereoorlog, meen om verskeie redes dat hy "waarskynlik" meer "anti-Engeland as pro-Boer" was en dat die basiese motief vir sy skrywe in so 'n geval ook buite die teks van De crisis in Zuid-Afrika gesoek moet word.

Dit kan aanvaar word - Van Ruler het hierin gelyk - dat Kuyper as gereformeerde homself in die bree uitleg van sy denke oor jare heen getrou gebly het: vanaf sy Eenvormigheid, de vloek van het moderne leven in 1869 soos gelewer as 31-jarige predikant tot by sy Antirevolutionaire staatkunde... (1916) in die aandskemering van sy lewe as Christenstaatsman (Strauss, 1984:89). Die geldigheid van hierdie stelling word ook gehandhaaf deur Velema (1989:67) wat, hoewel ietwat anders getint, saam met Augustyn 'n klemverskuiwing in die konsentrasie van Kuyper se denke rondom 1885 poneer. 'n Buite-tekstuele verklaring vir Kuyper se standpunte in sy Plancius-rede en De crisis kan dus alleen 
dominant wees - dit sou andersins wel bykomstig kan wees - as hy hierin prinsipieel anders praat as in sy ander, groter werke. In die uitleg van laasgenoemde moet die breë oogmerke, datering en historiese konteks daarvan natuurlik ook in aanmerking geneem word.

\section{Kuyper: 'n breë denkraamwerk vir sy standpunt}

Vir die reliëf van Kuyper se standpunte oor ras en volk in die algemeen moet ons aanknoop by sy leer oor die partikuliere en algemene genade ("gemeene gratie") 'n saak wat deur sy hele teologies-wysgerige denksisteem loop. Kuyper se leer van die tweërlei genade is veral uitgewerk in 'n artikelreeks in De Heraut vanaf 1895 tot 1901 (Velema, 1989:63). Hierdie artikelreeks ontstaan dus in min of meer dieselfde tyd as De crisis.

Volgens Kuyper bring die algemene genade, na die intrede van die sonde in die wêreld, die verborge kragte wat reeds in die skepping opgesluit was, tot ontwikkeling. Hierdie verborge kragte is egter nie bo-natuurlik nie, maar natuurlik en werk in die skepping soos die regeneratiewe vermoe van die inenslike liggaam waardeur die wond self genees en die natuur homself herstel (s.j.(a):i:257; s.j.(a): ii:218; s.j.(a):iii:107-110). Hierdie herstel kom egter nie deur en deur selfstandig - uit die algemene genade self - na vore nie. God moet nog altyd help met ' $n$ soort 'intredende genade' wat bestaan uit die leiding en bestuur van die kragte in die natuur. "Gratie" setel immers nie in die mens self nie, maar word hom toegevoeg (s.j.(a):iii:78-79). So is "gemeene gratie" verantwoordelik vir die ontplooiing van die "scheppingspotenties" wat in die menslike geslag verborge lê en baan dit die weg tot die "collectieve voltooiing" van die beeld van God in die menslike kultuur (Van Ruler, s.j.:33).

Wat die algemene met die besondere genade in gemeen het, is dat dit van dieselfde God is; dit is egter nie dieselfde soort genade nie. Die algemene genade werk uitwendig en temperend op die sonde in die wêreld in - soos 'n koue waterbad vir een met tifuskoors, terwyl die besondere genade inwendige medisyne vir die siekte verskaf (Kuyper, s.j. ii:25).

Die algemene genade verhoed "hel op aarde", verskaf die moontlikheid vir die kerk om te vestig en vir die mens on vatbaar te wees vir die Evangelie, terwyl die besondere genade deur die kerkinstituut lei tot wedergeboorte (Van Ruler, s.j.: 13,51). Die algemene genade is dus die terrein waarop of die gestalte waarin die besondere genade sigbaar word: die algemene genade dien as aanvulling of nadere presisering van die besondere genade.

Volgens Kuyper funksioneer die algemene genade op die nie-kerklike terreine van die samelewing en die besondere genade uitsluitlik in die georganiseerde kerk. Slegs binne hierdie mure brand die lamp van die Christelike religie. Die lig 
daarvan straal egter deur die vensters heen na 'buite' en val so op alle geledinge van die gemeenskap (s.j.(a):ii:272-275). Hierdie lig, soos gedra deur die weergeborenes, vorm die invloed van die kerk in die samelewing - deur Kuyper tuisgebring onder die uitdrukking "kerk as organisme" (s.j.(a):ii:259-260, s.j.(a):iii: 425; Velema, 1989:67). En, hoewel die besondere genade sy aanknopingspunt of voorwaarde (die holte vir sy voet - Velema, 1989:64) in die algemene genade vind, bring dit die bevrugting en voltooiing, of optimale ontwikkeling daarvan teweeg (s.j.(a):i:220). Die werking van die algemene genade kan dus nie sonder God nie, maar beskik tog oor ' $n$ eie ruimte, 'n relatiewe selfstandigheid: God lei en bestuur immers net. Terwyl die kerk onder die besondere genade staan en vanuit die Bybel gerig word, staan die nie-kerklike lewenskringe onder die algemene genade waarin die ontwikkeling van skeppingskragte 'n belangrike plek inneem.

Volgens Kuyper werk die algemene genade, los gedink van die besondere genade en in gemeenskappe of nasies waarin die deurwerking van die Evangelie nie merkbaar is nie, op twee maniere. (Kuyper gebruik die begrip nasie meestal in staatkundige sin.) Die genadewerking word getipeer as algemeen, as dit alle mense raak, en as spesiaal, byvoorbeeld as daar in spesifieke lande (bv. Meksiko, Peru, Indië, Japan en China) 'n geïsoleerde, dog hoër ontwikkelingsvorn sigbaar is (Kuyper, s.j.(a):ii 177-181). Op 'n nog hoër vlak van ontwikkeling staan "gekerstende gemeene gratie": dit kom voor in samelewingsgeledinge waarin die besondere genade domineer sonder dat die persone daarin weergeborenes is. Die hoogste vlak van ontwikkeling kom eers deur die inwerking van die besondere genade in die harte en lewens van mense - die eintlike Christelike beskawing (Kuyper, s.j.(a):ii:671-672: iii:304).

Soek ons na 'n sleutel by Kuyper vir die verstaan van die vraag oor hoe sy soort samelewingsontwikkeling ontstaan, stuit ons op twee antwoorde: samelewingsontwikkeling is bloot histories waarneembaar, maar ook te verklaar aan die hand van 'n organiese beginsel in die skepping. Ten opsigte van laasgenoemde noem Kuyper die menslike lewe "een oneindig saamgesteld organisme" (Kuyper, 1930: 10). Samelewings en samelewingstrukture ontwikkel organies omdat die normalé lewe uit "zichzelf opwassen" of "uit het leven zelf opkomt" (Kuyper, s.j.(a):iii: 91).

Gekoppel aan die relatiewe selfstandigheid van die algemene genade (teenoor God) en die natuurwetmatige, biotiese aard van die begrip organies, word hiermee ' $n$ noodwendigwerkende oerbeginsel by Kuyper blootgelê wat korrespondeer met die uitgangspunt van die Idealisme. Juis in De crisis gebruik Kuyper ook die term organies vir historiese groei (1900:37). Op hierdie punt is dit betekenisvol dat Velema (1989:69) van 'n dialektiese verhouding tussen algemene en beson- 
dere genade by Kuyper praat: "Deze verbinding is exponent van Kuypers Idealistische schering met een Gereformeerde inslag."

Dit bring ons by Kuyper se standpunt oor Christelike beskawingsontwikkeling onder rasse en volke en die antwoord op die vraag of sy standpunte oor die SuidAfrikaanse situasie van destyds hiermee ooreenkom.

\section{Kuyper, volkereverskille en Suid-Afrika}

Vanuit sy perspektief van die algemene genade is Kuyper oortuig dat God se plan met die wêreld, naamlik die verwerkliking van die skeppingsmoontlikhede, deurgaan. Die sonde vreet wel soos 'n wurm aan die vrug, maar dit kan die ontwikkeling en rypwording daarvan nie keer nie (s.j.(a):ii: 121). Onder die voorsienige regering van God deur die algemene genade, is alles gerig op 'n "gekozen doel" en lê dit in die lyn van skepping-historie-heerlikheid (s.j.(a):ii:600, 605, 610). Hierdie stelling geld ook vir die menslike geslag

In een breede vertakking van allerlei volkeren en natien, tongen en talen, heeft God, met zeer verschillende graad van ontwikkeling, al de schatten, die Hij in ons menschelijk geslacht verborgen had, weten uit te brengen... (s.j.(a):ii: 121).

In bogenoemde aanhaling het albei terne ('volke' en 'nasies') 'n volkstaatkonnotasie (vgl. Kuyper, s.j.(a):ii:43).

Kragtens die skepping was die menslike geslag een magtige organisme wat hom bloot langs geslagslyne organies uit een bloed en gees na liggaam en siel ontwikkel het $(1912: 229,231,232,237-239,256)$. Hierdie organiese samehang sal sy voltooiing weer in die koninkryk van die hemele vind, maar intussen het daar met die gebeure by Babel ' $n$ verandering in die Regimen Dei gekom. Deur die spraakverwarring van Genesis 11 het God 'n psigiese wonder laat plaasvind waarin die verskille tussen nasies en volke in die menslike bewussyn vasgelê is. Vanuit hierdie bewussyn ontwikkel die eie "origine en type" van elke volk en nasie organies en beweeg dit langs 'n eie lyn voort, elk met 'n eie "stroomwet", taak en plek op aarde (s.j.(b)ii: $45,66,67$ ). In 'n vroeëre fase praat Kuyper van die huisgesin as die primêre orgaan van die samelewing waaruit die "geest" van die volk (dit is 'n bepaalde samelewing, soos Nederland) organies groei (1870:33). Harmoniese intervolkige verkeer is wel moontlik indien die organiese proses sy volle loop neem (s.j.(a):iii:282; 1870:7).

Die volksidealistiese inslag (volksgees deur middel van 'n organies-biotiese groeiproses as lewensbeginsel) by hierdie opvattings van Kuyper is dus ten oorvloede toe duidelik. In die lig van Kuyper se uiteensetting van die werking van die "gemeene gratie" is dit wel 'n vraag waar hy die oorsprong van volkereverskille 
plaas: in die kragte van die skepping ("scheppingspotenties") of by die gebeure by Babel? Gaan dit om statiese prinsipes wat steeds onder Gods voorsienigheid tot aktualisering moet kom - albei moontlikhede soos deur Kuyper geformuleer, laat die opening hiervoor - of gaan dit om 'n keusevryheid by die mens wat hy onder Gods voorsienigheid in die loop van die geskiedenis uitoefen? Die ontstaan en groei van die Afrikaner was en is immers op die tweede manier.

Op hierdie punt is dit ter sake om te vermeld dat F.J.M. Potgieter in 1956 Kuyper se denke so interpreteer dat hy die oorsprong van die volkereverskille na Babel terugvoer. Met die volkereverskeidenheid of veelvormigheid in Kuyperiaanse sin as uitgangspunt, gaan hy egter 'n eie geinterpreteerde treetjie verder as Kuyper self: "... daar kan (in die lig hiervan) geen pleidooi vir integrasie" in Suid- Afrika wees nie (Potgieter, 1956:9). Die verskil met Kuyper is dat laasgenoemde nie volkereverskille nie, maar beskawing as uitgangspunt vir die 'apartheid' van sy tyd gebruik. Du Preez gaan dieselfde weg as Potgieter op en praat van die "sielkundige vaslegging" van die volkereverskille by Babel (Die Kerkbode, 195003-18). So verword afsonderlike ontwikkeling by sowel Potgieter as Du Preez, met 'n twyfelagtige beroep op Kuyper, tot 'n diskriminerende, geslote sisteem, terwyl dit by laasgenoemde 'n oopkantigheid vertoon: "om hem eens met u gelijk te maken". Potgieter (1956:11) regverdig wel die ontstaan van die Afrikaner uit verskillende groepe met die argument dat dit God se wil was en nie wesenlik aan die bestaande veelvonnigheid verander het nie. As sy motivering vir die daarstelling van apartheid egter konsekwent gehandhaaf sou word, was die Afrikaner in sonde ontvang en gebore.

Hoewel hy dit nie grondig uitwerk nie, toon Kinghorn (1986:60,61), vanuit Kuyper se posisie gesien, tog die meer korrekte weg aan as hy suggereer dat Kuyper se beskawingsfilosofie, binne sy lewensbeskoulike raamwerk, Afrikaners soos J.D. Kestell tot hulp kon gewees het in hulle steun aan apartheid. Hy gee egter toe dat hierdie sake nog wag op meer volledige ondersoek $(1986: 60,61)$.

\section{Kuyper, beskawing en Suid-Afrika}

Om nou die verskille in ontwikkeling onder die volke, soos hy dit noem, te verklaar, koppel Kuyper die begrip van 'n Christelike beskawing aan sy opvatting van die algemene en besondere genade. In 'n bloot historiese beskouing van die stand van sake, onderskei hy vier beskawingsvlakke in die wêreld van sy tyd: die laagste beskawingsvlak word aangetref in Afrika wat slegs deel aan die algemene werking van die algemene genade het. Dan volg Asië, Meksiko, en so meer, wat deel aan die spesiale werking van die algemene genade. Vervolgens is dit die lande om die Middellandse See wat ook in die "gemeene gratie" deel, maar omdat hierdie lande in die eerste eeue na Christus met die vrug van die besondere genade in aanraking was, staan hul op 'n hoër vlak van ontwikkeling. Die mees 
voortreflike beskawingsvlak, volgens Kuyper, is die Europees-Amerikaanse of Christelike beskawing waarop die besondere genade so duidelik deurgewerk het (s.j.(a):ii:668-671).

Wat Afrika aanbetref - Kuyper is hier teen die einde van die vorige eeu aan die woord - wys hy op die voorkoms van kannibalisme, 'n onontwikkelde letterkunde, mense wat ongekleed en in hutte leef en 'n gebrek aan ontwikkeling in staatsinrigting, kuns en wetenskap. Hierteenoor het die intrede van die Christendom en meer spesifiek die Calvinisme, tot so ' $n$ mate in die Weste - en die gekolonialiseerde soom van Afrika waaronder die Boere hulle ook bevind gedomineer (besondere genade sowel as gekerstende algemene genade), dat dit tot 'n hoër en ryker samelewingsontwikkeling aanleiding gegee het (s.j.(a): ii:668669; 1943:41). In sy Stone-lesings van 1898 in die Verenigde State roem hy die "heroism of old Calvinism" van die Boere in die Eerste Vryheidsoorlog by die slag van Amajuba (1881) en met die verydeling van die Jamesoninval (1896). Wat meer is, "If Calvinism had not been passed on from our fathers to their African descendants, no free republic would have arisen in the South of the Dark Continent" (1943:40). Min of meer in dieselfde tyd verklaar Kuyper dat die Groot Trek van Afrikanerboere (1835-1838) uit die destydse Kaapkolonie deur God "gewekt" en bepalend vir die toekoms van Afrika, selfs vir die wêreld is (s.j.(a):i:306)! En dit kan uit Kuyper se oogpunt alleen waar wees omdat hy in die Boere die draers van die besondere genade en Christelike beskawing in hulle deel van die wêreld sien.

Lewensbeskoulik plaas Kuyper die Trek in dieselfde raam as hy in De crisis opmerk dat die Boere inderwaarheid uit 'n moderne Egipteland getrek het (1900:14). Met die oog op ' $n$ vergadering van burgers in dieselfde tyd verwys hy ook goedkeurend na die gesinshoof of Boerepatriarg as 'n goeie voorbeeld van sy oortuiging dat die volk organies uit die gesin ontwikkel en dus ook van 'n gedesentraliseerde regering van oudstes kan gebruikmaak (s.j.(a):iii:89,90). Soos in sy Planciusrede van 1884, bly die Boere stam- en geesgenote, beskawingsgenote van die Nederlandse volk wat volgens Kuyper "uitgesproken van het Gereformeerde type" is (s.j.(a):ii:677;i iii:519). Ook die Europese volksverhuisings wat onder meer tot die vestiging van die volk in Nederland gelei het, skryf Kuyper toe aan die ingrype van God. Dit was die "Hooger hand" wat die "geest" in hierdie volke gestuur het om so te handel (1912:339). Juis vanuit sy organiese of kollektiewe beginsel - vanuit sy volksromantiese skering - kan Kuyper so veralgemenend gloedvol en byna sentimenteel van die Boer en sy Nederlandse 'stamgenoot' praat. Hierteenoor toon die Nederlandse historikus, G.J. Schutte (1986:169), byvoorbeeld aan dat die gereformeerdes of Calviniste in Nederland reeds in Kuyper se tyd 'n grootliks aparte bestaan as 'n klein "smaldeel" van die totale bevolking gevoer het. Die bestaan van rewolusionêre 
libertynse staatsopvattings onder sommige Boere is ook bekend (Van Schoor \& Van Rooyen, 1960:122).

Vanuit dieselfde beskawingshoek betrek Kuyper ook die nageslag van Noag se drie seuns en daarmee by implikasie ook die swartes in Suid-Afrika - vir hom die nageslag van Gam. In afwyking van wat hy vroeër oor die Afrikabeskawing en die werking van die algemene genade gesê het, beweer Kuyper op 'n ander plek dat sowel die algemene as die besondere genade ontbreek op hierdie beskawingsvlak wat verteenwoordig word deur die kinders van Gam. Die kinders van Gam staan in sy oë op die heel laagste vlak van mensontwikkeling - hy noem die Zoeloes in hierdie verband by name (s.j.(a):iii:304,305) - en hy beskou hul dus as onderhorig aan sowel die nageslag van Jafet (by wie die algemene genade darem deurgewerk het) en Sem (by wie albei soorte genades deurgewerk het) (Kuyper, s.j.(b):40)! Volgens Kuyper kon die nageslag van Gam gevolglik "nimmer tot betekenis komen" (s.j.(a):i:303): die resultaat van die vloek waaronder hulle volgens die Plancius-rede "gebogen liggen". Hy staan ook daarop dat volke die vryhede en regte moet kry wat pas by hulle vlak van ontwikkeling (s.j.(a):iii:79) en een of ander vorm van demokrasie onder die anderskleuriges van Afrika sal nie sy steun kry nie.

\section{Kuyper bly getrou aan homself}

Kuyper handhaaf in sy Plancius-rede en De crisis dus dieselfde denksisteem ten opsigte van beskawing as elders in sy werke. Sy beskouing in eersgenoemde stem ooreen met wat hy oor die ontwikkeling van die menslike samelewing in omvattende sin en vanuit die deurwerking van die besondere en algemene genade - as teologies-wysgerige raamwerk - stel. Selfs die konkretisering van sy voorbeelde oor ras en volk en Suid-Afrika teen die einde van die vorige eeu, vind weerklank in sommige van sy ander werke. In sy standpunt oor die 'apartheid' van sy tyd bly Abraham Kuyper aan sy eie breë denksisteem getrou!

' $n$ Vraag wat hieruit ontstaan is of Kuyper in genoemde twee publikasies dan nog doelbewus by sy grondstelling bly dat Christus soewerein bo alle denke is. Die antwoord lê in die trant van sy betoog opgesluit: in die erkenning van die soewereiniteit van Christus is die Christelike beskawing en die lewensrigting van die Calvinisme óók op die spel.

Hierdie invalshoek geld ook sy Eurosentriese kulturele meerderwaardigheid - by Kuyper ' $n$ vaag omlynde, histories-bioties gefundeerde begrip waarin die besondere genade ook meespeel. In sommige van sy tiperings vir beskawing is hy ' $n$ tipiese Europeër van die negentiende eeu. Dit is dan ook nie buitengewoon dat ander teoloe in Nederland in hierdie tyd by Kuyper aansluiting vind of dieselfde klanke ten opsigte van Christendom en beskawing laat hoor nie (vgl. C. Spoel- 
stra, J.W. Gunning en B. ten Kate, Strauss, 1983:80, 502). Dit is origens bekend dat koloniale Europa nie demokraties in sy koloniale gebiede opgetree het nie en dat die Nederlanders in Nederlands-Oos-Indië (Indonesië) op hierdie stadium ook teen gelykstelling gekant was. Selfs die Nederlandse Zendingsbode van 24 November 1899 noem dit 'n gevaar vir die Christendom en alle Christene wat daarby betrokke is (Strauss, 1983:80).

Die vraag ontstaan dus of Kuyper ' $n$ rasbepaalde verskil in beskawing leer. Die antwoord hierop is ongetwyfeld negatief. Hy voorsien immers in sy rede van 1884 die moontlikheid dat die Boere die anderskleuriges op ' $n$ stadium met hulle gelyk sal kan mak - 'n proses wat binne sy denkraamwerk ten minste beskawingsportuur of -gelykheid veronderstel. Daarby is daar ' $n$ vaagheid by Kuyper ten opsigte van die vraag oor wat hy met die begrip ras bedoel. Op 'n plek verwys hy na bloed- en rasseverskille as 'n saak wat opkom uit God se bestel. Verskille in ras en bloed het volgens hom by Babel tot stand gekom en elke ras het 'n eie roeping om die geheel van die menslike lewe te dien (1912:337). Dit wil dus voorkom asof hy ras hier in fisies-biotiese sin gebruik. En tog verwys hy na die opbou van rassehaat tussen Boer en Brit as gevolg van die Anglo-Boereoorlog in De crisis (1900:61). Dit is dus goed moontlik dat hy in dieselfde publikasie die tern "een lager ras" vir die anderskleuriges nie natuurwetmatig bedoel nie, maar in terme van beskawingsontwikkeling. Was beskawing natuurwetmatig rasgebonde en organies bepaald, was beskawing en beskawingsontwikkeling uitgesluit vir enige een buite die beskaafde ras. So 'n uitgangspunt sou ' $n$ vorm van rassisme wees wat die kwaliteit van jou menswees afhanklik stel van die fisies-biotiese sye van jou lewe, naamlik van jou voorkoms.

Die beginsel of uitgangspunt van beskawingsontwikkeling wat Kuyper ten opsigte van die apartheid van sy tyd aanlê, is wel algemeen geldend. Daarom kan hy in sy Stone-lesings voor mense uit die Calvinistiese invloedsfeer leer dat die Calvinisme by sy deurwerking in die samelewing homself uitdruk "in the democratic interpretation of life" (1943:27). De Gruchy is dus reg as hy meen dat Kuyper leer dat die Calvinisme demokraties is (1984:108). Die verskil is dat Kuyper die demokrasie wil aanwend in ' $n$ Calvinistiesgetinte samelewing - ' $n$ voorwaarde wat hy nie meen om in die Afrikakonteks te vind nie.

Teen hierdie tyd moet dit ook duidelik wees dat buite-tekstuele motiewe vir Kuyper se houding in sowel sy Plancius-rede en De crisis bykomstig en nie dominant van aard kan wees nie. Met hierdie geskrifte was Kuyper nie 'n blote simpatieke geleentheidspreker wat sy toehoorders na die mond wou praat nie. Hy was verder gekwalifiseerd pro-Boer, omdat hy laasgenoemde op ' $n$ bepaalde manier ingepas het in sy oortuigings en denkraamwerk. 


\section{Enkele slotgevolgtrekkings}

* Vanuit sy opvattings oor algemene en besondere genade waaruit hy 'n teologies-wysgerige beskawingsteorie ontwikkel het, kon Kuyper die apartheid van sy tyd onderskryf. Binne sy denkraamwerk was hierdie soort apartheid egter 'n tydsgebonde maatreël in ' $n$ fase van opheffing of beskawingsontwikkeling.

* Hoewel Kuyper vanuit sy Europese agtergrond aan die begrippe nasie en volk feitlik deurgaans 'n volkstaats- en volkskulturele konnotasie gee, gebruik hy dit ongenuanseerd. Hoewel hy volk en staatsowerheid aan mekaar koppel, gee hy nêrens enige aanduiding dat hy die volkstaatsgedagte as normatief beskou nie. Terselfdertyd moet dit aanvaar word dat hy ook nooit ernstig gekonfronteer was met die gedagte van meer as een volk op een staatsgebied nie.

* In sy volksidealistiese opvatting oor die organiese uitgroei van die volksaard aan die hand van ' $n$ eie lewenskem, verskaf Kuyper wel 'n aanknopingspunt vir 'n geslote apartheidsisteem. Hierdie opvattings verteenwoordig egter 'n nie-Christelike deel van sy denke, 'n oorblyfsel van die ou Kuyper, van voor 1867 (vgl. Velema, 1989:70). In die lig van die 'oop' toepassing van sy beskawingsargument op Suid-Afrika is dit onwaarskynlik dat Kuyper vir ' $n$ statiese geslote sisteem sou kies.

\section{Bibliografie}

DE GRUCHY, J 1979. The Church Struggle in South Africa Grand Rapids Eerdmans

DE GRUCHY, J 1984 Bonhoeffer and South Africa Grand Rapids : Eerdmans

KINGHORN, J red. 1986 Die NG Kerk en apartheid Johannesburg : Macmillan.

KUYPER, A. 1870 . Eenvormigheid, de vloek van het moderne leven Amsterdam : sa (2e druk).

KUYPER, A. 1884. Plancius-rede. Amsterdam : Kruyt.

KUYPER, A. 1900. De crisis in Zuid-Afrika. Amsterdam : Hoveker en Wormser

KUYPER, A 1912. Pro Rege iii Kampen: Kok

KUYPER, A 1930. Souvereiniteit in eigen kring Kampen Kok (3e druk)

KUYPER, A 1943. Calvinism - Six Stone Foundation Lectures Grand Rapids Eerdmans

KUYPER, A s.j(a) De Gemeene Gratie i,ii,iii Kampen : Kok (4e onveranderde druk)

KUYPER, A sj.(b) De overheid-locus de magistratu Kampen : Kok

LUBBE, J J \& BRITZ, R M 1992 Abraham Kuyper oor die Anglo-Boere-oorlog: 'n krisis in Suid-Afrika, of ' $n$ krisis in Europa? Ongepubliseerd

NEDERDUITSE GEREFORMEERDE KERK (NGK) 1966. Agenda en Handelinge van die Algemene Sinode

POTGIETER, FJM 1956 Veelvormige ontwikkeling die wil van God Bloemfontein Sacum.

POTGIETER, FJM 1978 Eenheid en veelvormigheid prinsipieel verantwoord ( $l n$ Vorster, J D red., Veelvormigheid en eenheid Kaapstad : NG Kerk Uitgewers p 9-36.) 
RIDDERBOS, S J. 1947 De theologische cultuurbeschouwing van Abraham Kuyper. Kampen : Kok.

SCHUTTE, G.J. 1986. Nederland en de Afrikaners - adhesie en aversie Franeker: Wever.

SMIT, D.J. 1992. Reformed Theology in South Africa - A Story of Many Stories Acta Theologica, 12(1):88-110.

SMIT, J.H. 1989. Abraham Kuyper en volksideologie onder Afrikaners In die Skriflig, 23(91):45-55.

STRAUSS, P.J. 1983. Die Nederduitse Gereformeerde Kerk en die Gereformeerde Kerke in Nederland: Betrekkinge rondom die Suid-Afrikaanse rassevraagstuk Pretoria : UP (Ongepubliseerde D D-Proefskrif.)

STRAUSS, P J. 1984. Nogeens Abraham Kuyper, ras en volk en Suid-Afrika. Tydskrif vir Christelike Wetenskap, 20(1):89-97

VAN RULER, A.A. s.j. Kuypers idee eener christelijke cultuur. Nijkerk: Callenbach.

VAN SCHOOR, MCE. \& VAN ROOYEN, J J. 1960. Republieke en Republikeine Kaapstad Nasionale Boekhandel

VAN WYK, J A 1978. Teologie en ideologie Sovenga : Studiegroep "Kerk en wêreld"

VELEMA, W.H. 1989. Kuyper als theoloog - een persoonlijke evaluatie na dertig jaar In die Skriflig, 23(91):56-73

VERKUYL, J e a 1968. Verantwoorde revolutie Kampen : Kok

VILJOEN, A.C. 1980 Trends in the Ecumenical Movement and the South African Churches (In Vorster, W.S ed. Church Unity and Diversity in the South African Context Pretoria : Unisa p. 22-49.) 